\title{
Tertiary Education Trust Fund Interventions and Sustainable Development in Nigerian Universities: Evidence from Ebonyi State University, Abakaliki
}

Larry E. Udu ${ }^{1} \&$ Joseph Okwesili Nkwede ${ }^{2}$

${ }^{1}$ Department of Public Administration, Ebonyi State University, Nigeria

${ }^{2}$ Departmentof Political Science, Ebonyi State University, Abakaliki, Nigeria

Correspondence: Larry E. Udu, Department of Public Administration, Ebonyi State University. E-mail: Lamaken.larryudu503@gmail.com

Received: June 25, 2014 Accepted: June 28, 2014 Online Published: July 31, 2014

doi:10.5539/jsd.v7n4p191

URL: http://dx.doi.org/10.5539/jsd.v7n4p191

\begin{abstract}
The study examined the impact of TETFund Interventions in Nigerian Universities and its implications for sustainable development with special attention on EBSU. Content Analytical Approach was adopted while Public Goods Theory was used as a theoretical framework. The study reviewed the contributions of scholars in this field.Data were extensively sourced from documentary papers from which the three major objectives of the study were accomplished.The study finds that TETFund Interventions in Nigerian Universities particularly EBSU have impacted positively on the infrastructural and human development of the institutions; the implications of this for sustainable development is also positive. The study recommends amongst others, a reduction and/or total elimination of unhealthy bureaucratic bottlenecks involved in accessing TETFund; utilization of honest and competent contractors in executing TETFund projects and involvement of donor agencies to assist governments in funding tertiary education in Nigeria.This, if tenaciously adhered to, will launch Nigerian Universities to a better footing.
\end{abstract}

Keywords:TETFund, EBSU, sustainable development, intervention

\section{Introduction}

\subsection{Background of the Study}

Ebonyi State, Nigeria faced severe shortage of professional and skilled manpower at its creation in 1996. This is because, when the new state was carved out from the then Abia and Enugu States, Civil and Public servants who were indigenesofthese states, relocated accordingly to their parent states leaving a handful of civil servants of Ebonyi State origin who also relocated from Enugu and Abia, to work at the state civil/ public service.

There was no Federal or State University to train professionals and skilled manpower which the state direly needed. Ebonyi State was then classified by the National Universities Commission (NUC), as an educationally backward state. The United Nations Development Programme (UNDP) report in 2001 also, ranked Enugu/Ebonyi law (0.466) in the Human Development Index (HDI), on the basis of physical Health and Education (Udu, 2009).

Ebonyi State, being one of the South-East States (from the old Eastern Region), was one of the theatres of hostility during the 30 months civil war in Nigeria between 1967-1970). The vicious war, injustices and obnoxious post-war policies of marginalization of past administrations in Nigeria, devasted and stifled economic growth and education in Ebonyi State.

The above Scenario informed the introduction of free and compulsory primary and secondary education by the Sam Egwu led administration in 1999. The reason for this was to start from the roots to prepare candidates for university education which ultimately, is believed to, with time, address the manpower needs of Ebonyi State.

Similarly, the Sam Egwu administration, in the year 2000, ungraded the Ebonyi State University to autonomous status.

In addition to its educationally backward status, Ebonyi State is also one of the poorest states in Nigeria. The major means of livelihood is subsistent farming, artisanship and petty business outfits. The result of this is that 
many parents cannot afford university education for their children.

Essentially, the major sources of funding for the university is the Ebonyi State government monthly subvention and internally generated revenue which comes basically from school fees. The inadequacy of this source of funding has recently compelled management of the university to increase school fees. As a result, many indigent students were forced to drop out while enrollment of students of Ebonyi State origin has subsequently declined.Nkwede (2009) aptly pointed out that University education in the contemporary Nigeria has focused itself at the cross-roads in the wake of continued lack of funding from the traditional sources even when it is explicitly clear that education is one of the most viable and biggest industries in almost every modern economy.

Inadequate funding has resulted to poor infrastructural facilities, teaching/learning facilities; library, research, etc are also in very short supply. The problem of funding is however, not peculiar to Ebonyi State University. As noted by Mgbekem (2006), cited in Oscar (2012), the major challenge facing the management of university system in Nigeria, is inadequate funding. Besides, Ajayi and Ekundayo (2006), also remarked that the Nigerian government over the years, has not been meeting the United National Educational Scientific and Cultural Organization (UNESCO), recommendation of $26 \%$ of the local budget allocation to Education Sector. In view of this, the Tertiary Education Trust Fund (TETFUND) was established as an intervention agency under the Education Tax Act No. 7 of 1993, (ETF, 2011).Ebonyi State University had its first allocation of TETFUND Intervention in 2000 (EBSU-TETFund Desk Office, 2000).

It is against this backdrop that this paper aims at examining the TETFund Interventions in Nigerian Universities with special attention on Ebonyi State University from 2000-2012 and its implications for sustainable development of the University.In doing this, the study is divided into six sections.Section one delved into the general background of the study bringing objectives of the study, hypotheses and theoretical framework to bear.Section two dealt with the conceptualization of sustainable development, TETFund and the historicity of Ebonyi State University.Section three captured methodology employed in the study.Section four focused on the discussion and analysis of findings while section five and six wrapped it up with conclusion and recommendations.

\subsection{Objectives of the Study}

The specific objectives are:

1) To ascertain the relative effect of the TETFund Intervention on infrastructural development in Ebonyi State University;

2) To determine the impact of TETFund intervention on Staff development in the University.

3) To determine the impact of TETFund intervention on Research and academic growth in Ebonyi State University.

\subsection{Hypotheses}

1) TETFund intervention has significantly contributed to Infrastructural Development in EBSU

2) TETFund intervention has impacted positively on staff development in EBSU

3) TETFund intervention has significantly enhanced research and academic growth in EBSU.

\subsection{Theoretical Framework}

The study adopted the Public Goods Theory by Samuelson (1994).The Public goods theory has two main assumptions:

1) A good once produced for same consumers can be consumed by additional consumers at no additional cost.

2) There is non-excludability which means that it is difficult to keep people from consuming the good, once it has been produced.

According to Samuelson, Goods with these characteristics will be under-produced in the private sector, or may not be produced at all.Following the conventional wisdom, economic efficiency requires that the government forces people to contribute to the production of public goods, and, then, allow all citizens to consume them.A public good is a good produced by government and generally made available for the benefit of its citizens.

The explanation of 'public' by Narain (1986) throws more light to the public goods analysis.For Narain (1986), there are three characteristics of "publicness"

(a) Public purpose (b) Public ownership,and (c) Public control.For this study, education is a public good.The public goods theory provides justification for large public expenditure in education. This is based on the 
assumption that it is only the government that can effectively provide education services appropriately to the citizens given the varied externalities associated with it.

Ebonyi State University is a public enterprise, owned and controlled by the government for the public interest/purpose; hence, demands accountability from the University authorities.Evidently, the injection of TETFund projects into Ebonyi State University ensures that goods (education) with public -goods characteristics are efficiently and effectively provided.By so doing, education as "public good is made available and affordable to the greater majority- a situation that foster government as well as its stakeholders interest/benefits.

\section{Conceptual Issues}

\subsection{Sustainable Development}

Sustainable development is a new and broad generic term which pegs specific application to distinct political economies.Eboh (1995) was right when he noted that only very few (if any) inter-disciplinary concept, posses presently, greater intellectual challenge for scholars and policy analysts than 'sustainable development'. This, he explains, is because of the cross-disciplinary sensibilities which the concept involves; thereby, making a universal definition far-fetched.The situation is not helped by the fact that countries in different stages of development and with varying socio-political and economic structures cannot reasonably subscribe to the same definitional regime.Thus, definitional and paradigmatic differences characterize the intellectual discourse on sustainable development.

The sustainability concept is a modern world concept which refers to long-term human and material sustenance.It ensures the continued existence of programmes long after their establishment (Abah, 2003).Sustainability is central to all development efforts. Without it, investments in the development effort are short-lived and of no effect.It is the only global barometer for measuring a resilient and enduring socio-economic system.A programme's results are called sustainable if they are utilized by the direct recipients after the completion of the programme without further external assistance (UNDP Management Programme, 2001).

In more broad and encompassing definitions, sustainable development is defined as development that meets the needs of the present without even compromising the ability of future generations to meet their own needs. The definition as expounded by the World Bank Commission on Environment and Development (WCED) (1987) and cited in Nduanya (2001), builds development efforts on man, whom it was believed, should be the purveyor and end of development efforts.

Sustainable development has to do with participatory development, human development and environmental protection. These are measured by the Human Development Index (HDI).The Human Development Index combines a measure of purchasing power with measures of physical habitat and educational attainment.The three components of HDI offer an alternative to Gross National Product (GNP) for measuring the relative socio-economic progress of nations.It enables people and their governments to evaluate progress over time and to determine priorities for policy interventions.It also permits instructive comparisons of the experiences in different countries (UNDP, 1994).

In 1990, after the Structural Adjustment Programmes which had moved development away from concerns for the people to concerns for macro-economic aggregates, the world needed to be reminded that people are the real wealth of a nation and that the basic objective of development is to create an enabling environment for people to enjoy long, healthy and creative lives (Human Development Report, 1990).Thus, the HDI devised by the UNDP, has opened a new vista for measuring and evaluating development in a more human-centred rather than economistic manner.

If sustainable development is participatory and human-centred amongst other aspects as noted above, its indicators for our use in this study as it concerns TETFund interventions in Ebonyi State University shall comprise: level of lasting infrastructural facilities - libraries, conducive environment for teaching/research, staff capacity development, output and students' performances; etc.

\subsection{TETFund AS an Intervention Agency}

The Tertiary Education Trust Fund (TETFund) was established as an Intervention Agency under the Education Tax Act No. 7 of 1993.Tertiary Education Trust Fund (Establishment, Et.c) Act, 2011 repeals the Education Tax Act Cap. E4, laws of the Federation of Nigeria, 2004and Education Tax Fund Act No. 17, 2003 and establishes the TertiaryEducation Trust Fund charged with the responsibility for managing, disbursing and monitoring the education tax to public tertiary institutions in Nigeria.To enable the TETFund achieve the above objectives, TETFund Act, 2011 imposes a 2 percent (2\%) Education Tax on the assessable profit of all registered companies in Nigeria. The Federal Inland Revenue Service (FIRS) is empowered by the Act to assess and collect Education 
Tax. The fund administers the tax imposed by the Act and disburses the amount to tertiary educational institutions at Federal and State levels.It also monitors the projects executed with the funds allocated to the beneficiaries.

The mandate of the fund as provided in section 7 (1) (a) to (e) of the TETFund Act, 2011 is to administer and disburse the amount in the fund to Federal and State tertiary educational institutions, specifically for the provision and maintenance of the following:

1) Essential physical infrastructure for teaching and learning;

2) Instructional material and equipment;

3) Research and publication;

4) Academic Staff Training and Development;

5) Any other need which, in the opinion of the Board of Trustees, is critical and essential for the improvement of quality and maintenance of standards in the higher educational institutions (http://tetfund.gov.ng, Saturday, February1,2014).

From the above, it would have been clear that TETFund cardinal objective was to generate additional income to support tertiary education, provide scholarship and grants for the needy but promising students, attempting not only to strengthen and diversify the economic base of higher institutions in Nigeria but also redirecting their resources towards improving the productivity and quality of higher education.

\subsection{Ebonyi State University before TETFund Interventions}

What is today known as Ebonyi State University metamorphosed from the Anambra State University of Science and Technology (ASUTECH) law 7 of 1980.The ASUTECH Edict No. 20 of 1985, put in place a four-campus structure with the faculties of Agricultural Sciences and Veterinary Medicine located in Abakaliki.In 1987, a Pre-Science School (preliminary programme) was established in the Abakaliki campus of ASUTECH.On August 27, 1991, Enugu State was created out of the old Anambra State; so, ASUTECH campuses in Enugu and Abakaliki were inherited by Enugu State University of Science and Technology, ESUT, via Enugu State Government Edict No. 33, 1991 and amended in 1995 with the Abakaliki campus remaining as the new ESUT faculty of Agricultural Sciences.A year later, that is, in 1992, a college of Medicine was added.

At the creation of Ebonyi State in 1996, the Abakaliki campus of the then ESUT, was upgraded to Ebonyi State University College (EBSUC) by Edict No. 5 of Ebonyi State, 1998 and remained affiliated to ESUT.In 1997, the faculty of Applied and Natural Sciences with 8 departments was added to the fledging University and later in 1998, when the ESUT Pre-Science Programme was relocated to Nsukka, the EBSUC Pre-Degree School commenced lectures in both Sciences and Arts in replacement of the former.

However, the major landmark that launched the institution/college to her present status came in 1999 when Sam Egwu administration announced the upgrading of the University College to a full-fledged conventional university and the establishing law (Ebonyi State Law No. 7, 1999), received executive assents in January 14, 2000.

Resulting from the autonomous status, 4 additional faculties were created; viz: the faculties of Arts with six departments; Education, comprising six departments and Management and Social Sciences having nine departments.Also in the year 2000, the Faculty of Law and the School of Post-graduate Studies were established in addition to the Work and Study Programme (WASP) - a week-end programme mapped out for workers who desire University education while retaining their jobs.In 2002, a new faculty of Health and Technology was established.It took off in 2002/2003 academic year with departments of Nursing Sciences and that of Medical Laboratory Sciences.

Currently, the University is made up of 11 faculties, 60 departments, a Postgraduate School, Work and Study Programme, a Pre-Degree School; with a Staff Secondary and Nursery/Primary Schools (www.ebsu-edu.net; $7^{\text {th }}$ February, 2014).

The above, is a brief history of EBSU but our concern in this study is the institution's funding coupled with the attendant levels of infrastructural development prior to the TETFund intervention in 2000.Reacting to a press interview in Ogah (1999), stated inter alia that the major source of funding for the institution is students' school fees and Ebonyi State government monthly subventions.According to Ogah, fees were low (N8000) due to the State government education policy but salaries and emoluments of staff were fully borne by the state.In the interview, Ogah further stated that funds generated from fees were basically used for provision of stationeries and sundry administrative costs; with result, that, at the end of the day, there is hardly any fund available for 
infrastructural development.

To better understand the impact of the foregoing statements by the Ogah administration, it is pertinent to closely examine the population of students vis-à-vis the fees charged by the University.According to the Academic Planning Unit of the University (2000), the students population was a little above 10,000; the fees was N8000 (Eight thousand Naira).This being the case, it means that the total sum realized through students' fees was approximately, 80 million naira (ie 10,000x8000). The implication of the above scenario on the institution's state of funding is quite obvious. There was poor infrastructural development, library equipment, research materials and classroom accommodation were lacking/grossly inadequate.The University was housed in three different annexes, inherited from existing secondary school premises in the state.For instance, the CAS (College of Agricultural Sciences) annex situates at the former Agricultural Development Authority (ADA) housing the administrative block, the School of Postgraduate Studies, the Pre-Degree School and the faculties of Law and Agricultural Sciences. The Ishieke annex was inherited from the old Izzi High School premises, housing the faculty of Education, Management and Arts; while the College of Health Sciences (CHS) was inherited from the old Abakaliki High School, PRESCO.Structures in these annexes were in dilapidated forms and the University Management at that time, had to renovate same to usable standards through internally generated Revenue basically from School fees as aforementioned.

\section{Methodology}

Content Analytical Approach was adopted for this study.Data were collected using documentary instrument, direct observation and oral interviews with relevant officers and academic staff of Ebonyi State University who have direct connection with the TETFund disbursements and fund utilization in the University.

\section{Discussion}

\subsection{The TETFund Interventions in EBSU}

Ebonyi State University had its first TETFund Intervention in 2000.Records from the EBSU TETFund Desk Officer show the following disbursements to the University from $2000-2012.20,000,000$ in 2000; 43,80,000 in $2001 ; 78,500,000$ in $2002 ; 33,500,000$ in $2003 ; 33,500,000$ in $2004 ; 45,500,000$ in $2005 ; 45,500,000$ in 2006 ; $56,500,000$ in 2007; 127,000,000 in 2008; 127,000,000 in 2009; 553,140,000 in 2010; 395,000,000 in 2011 and $598,000,000$ in 2012 (EBSU TETFund Document, 2012). The above figures are also clearly placed in table 1 below.

Table 1. Details of TETfund allocation to EBSU(2000-2012)

\begin{tabular}{|c|c|c|c|c|c|c|c|}
\hline \multirow{2}{*}{\multicolumn{2}{|c|}{$\begin{array}{l}\text { Year of Intervention } \\
\text { Allocation Head }\end{array}$}} & \multirow{3}{*}{$\begin{array}{l}2000 \\
20,000,000\end{array}$} & \multirow{3}{*}{$\begin{array}{l}2001 \\
40,000,000\end{array}$} & \multirow{3}{*}{$\begin{array}{l}2002 \\
50,000,000\end{array}$} & \multirow{3}{*}{$\begin{array}{l}2003 \\
30,000,000\end{array}$} & \multirow{3}{*}{$\begin{array}{l}2004 \\
30,000,000\end{array}$} & \multirow{3}{*}{$\begin{array}{l}2005 \\
40,000,000\end{array}$} \\
\hline & & & & & & & \\
\hline a. & Normal intervention & & & & & & \\
\hline b. & Library intervention & & $3,500,000$ & $3,500,000$ & $3,500,000$ & $3,500,000$ & $5,000,000$ \\
\hline c. & Teaching practice & & & & & & \\
\hline d. & College of medicine & & & & & & \\
\hline e. & Staff training \& development & & 301,000 & $25,000,000$ & & & \\
\hline f. & Research grant & & & & & & \\
\hline g. & Publication of journal & & & & & & \\
\hline h. & Conference attendance & & & & & & \\
\hline i. & BOT special project & & & & & & \\
\hline j. & BOT special project II & & & & & & \\
\hline $\mathrm{k}$. & Publication of scholarly manuscript. & & & & & & \\
\hline 1. & Entrepreneurship development & & & & & & \\
\hline & & $20,000,000$ & $43,801,000$ & $78,500,000$ & $33,500,000$ & $33,500,000$ & $45,000,000$ \\
\hline
\end{tabular}




\begin{tabular}{|c|c|c|c|c|c|c|c|}
\hline \multirow{2}{*}{\multicolumn{2}{|c|}{$\begin{array}{l}\text { Year of Intervention } \\
\text { Allocation Head }\end{array}$}} & \multirow{3}{*}{$\begin{array}{l}2006 \\
40,000,000\end{array}$} & \multirow{3}{*}{$\begin{array}{l}2007 \\
52,000,000\end{array}$} & \multirow{3}{*}{$\begin{array}{l}2008 \\
67,000,000\end{array}$} & \multirow{3}{*}{$\begin{array}{l}2009 \\
57,000,000\end{array}$} & \multirow{3}{*}{$\begin{array}{l}2010 \\
193,140,000\end{array}$} & \multirow{3}{*}{$\begin{array}{l}2011 \\
175,000,000\end{array}$} \\
\hline & & & & & & & \\
\hline a. & Normal intervention & & & & & & \\
\hline b. & Library intervention & $5,000,000$ & $6,500,000$ & $10,000,000$ & $10,000,000$ & $20,000,000$ & $25,000,000$ \\
\hline c. & Teaching practice & - & - & - & $50,000,000$ & $60,000,000$ & $80,000,000$ \\
\hline $\mathrm{d}$. & College of medicine & - & - & - & $7,000,000$ & $10,000,000$ & $10,000,000$ \\
\hline e. & Staff training \& development & - & - & $50,000,000$ & $3,000,000$ & $5,000,000$ & $10,000,000$ \\
\hline f. & Research grant & - & - & - & - & $15,000,000$ & $20,000,000$ \\
\hline g. & Publication of journal & - & - & - & - & $200,000,000$ & - \\
\hline h. & Conference attendance & - & - & - & - & $50,000,000$ & - \\
\hline i. & BOT special project & - & - & - & - & - & - \\
\hline $\mathrm{j}$. & BOT special project II & - & - & - & - & - & - \\
\hline $\mathrm{k}$. & Publication of scholarly manuscript. & - & - & \multicolumn{2}{|l|}{-} & & \multirow[t]{2}{*}{$75,000,000$} \\
\hline 1. & Entrepreneurship development & - & - & & & & \\
\hline \multicolumn{2}{|c|}{ Total } & $45,000,000$ & $\mathbf{5 8 , 5 0 0 , 0 0 0}$ & $127,000,000$ & $33,500,000$ & $33,500,000$ & $45,000,000$ \\
\hline \multirow{2}{*}{\multicolumn{2}{|c|}{$\begin{array}{l}\text { Year of Intervention } \\
\text { Allocation Head }\end{array}$}} & \multirow[t]{2}{*}{2012} & \multirow[t]{2}{*}{ Total } & \multirow{2}{*}{\multicolumn{2}{|c|}{ Total amount accessed }} & \multirow{2}{*}{\multicolumn{2}{|c|}{ Total amount outstanding }} \\
\hline & & & & & & & \\
\hline \multicolumn{2}{|c|}{ a. Normal intervention } & $350,000,000$ & $1,144,140,000$ & 369,000 & & $775,140,00$ & \\
\hline b. & Library intervention & $53,000,000$ & $148,500,000$ & 19,000 & & $129,500,00$ & \\
\hline c. & Teaching practice & - & 301,000 & 301,000 & & - & \\
\hline $\mathrm{d}$. & College of medicine & - & $25,000,000$ & 25,000 & & - & \\
\hline e. & Staff training \& development & $130,000,000$ & $370,000,000$ & 287,167 & 06.66 & $82,832,193$ & \\
\hline f. & Research grant & $10,000,000$ & $37,000,000$ & 22,292, & & $14,707,980$ & \\
\hline g. & Publication of journal & $10,000,000$ & $28,000,000$ & - & & $28,000,000$ & \\
\hline h. & Conference attendance & $40,000,000$ & $75,000,000$ & 75,000 & & - & \\
\hline i. & BOT special project & - & $200,000,000$ & 200,000 & & - & \\
\hline $\mathrm{j}$. & BOT special project II & - & $50,000,000$ & 50,000 & & - & \\
\hline $\mathrm{k}$. & $\begin{array}{l}\text { Publication of scholarly } \\
\text { manuscript. }\end{array}$ & $5,000,000$ & $5,000,000$ & - & & $5,000,000$ & \\
\hline 1. & Entrepreneurship development & - & $75,000,000$ & - & & $75,000,000$ & \\
\hline To & & $598,000,000$ & $2,157,941,000$ & $1,047,7$ & 826.66 & $1,110,180,1$ & 3.34 \\
\hline
\end{tabular}

Source: EBSU TETFund Document, 2012.

From table 1 above, the total allocations to EBSU is N2,157,941,000.Records also show that out of this figure, a total of N1,047,760,826.66 representing 48.55 per cent has so far been assessed by the University while $\mathrm{N} 1,110,180,173.34$ representing 51.45 percent is still outstanding.This amount, according to the TETFund Desk Officer, EBSU (2012), includes the sum of N425,140,000 merged normal intervention for the 2009, 2010 and 2011 years.

Apparently, it becomes pertinent to examine these allocations vis-à-vis our Research objectives; which are hereunder restated for clarity purposes.

1) To ascertain the relative effect of the TETFund intervention on Infrastructural Development in Ebonyi State University;

2) To determine the impact of the TETFund Intervention on Staff Development in the University; and, 
3) To determine the impact of the TETFund Intervention on research and academic growth in Ebonyi State University.

\subsubsection{TETFund and Infrastructural Development in EBSU}

Table 2, shows the TETFund Intervention utilization for Infrastructures Development in Ebonyi State University for the periods under review.

Table 2. Normal intervention utilization

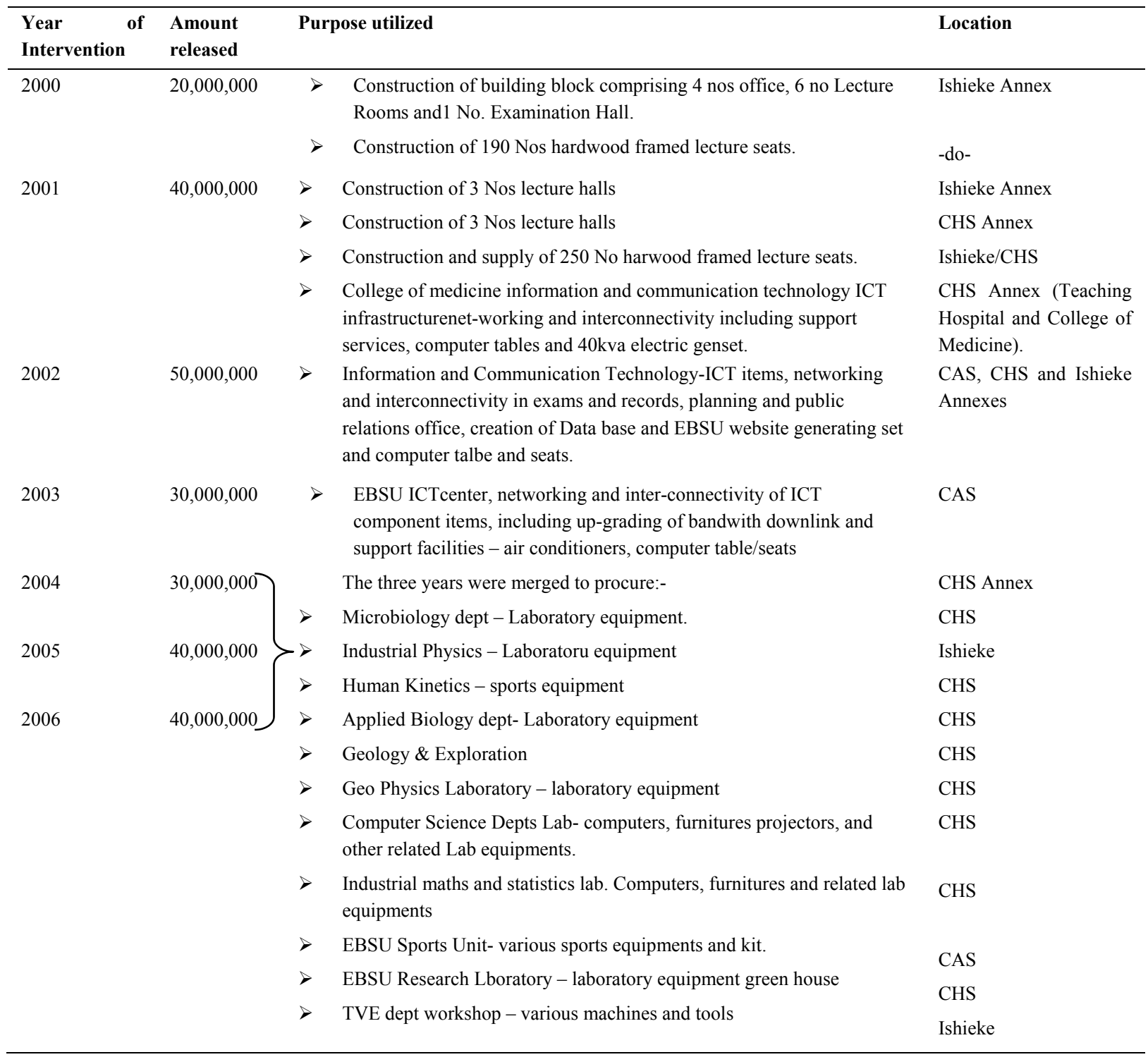




\begin{tabular}{|c|c|c|c|c|}
\hline $\begin{array}{l}\text { Year of } \\
\text { Intervention }\end{array}$ & $\begin{array}{l}\text { Amount } \\
\text { released }\end{array}$ & \multicolumn{2}{|c|}{ Purpose utilized } & Location \\
\hline 2007 & $52,000,000$ & \multicolumn{2}{|r|}{ The two years were merged and utilized on:- } & CHS \\
\hline \multirow[t]{7}{*}{2008} & $67,000,000$ & $>$ & & Main campus \\
\hline & & & Construction of TVE workshop building & Ishieke \\
\hline & & $>$ & Procurement of lecture theatre seats for FMS,FSS,FART & Main campus \\
\hline & & $>$ & Procurement and installation of lecture theater seats in FARM & CAS \\
\hline & & & Procurement of mass comm equipment - (printing machines and accessories). & CAS \\
\hline & & $>$ & $\begin{array}{l}\text { Procurement and installation of laboratory furnitures and fittings for soil } \\
\text { science and environmental management departments }\end{array}$ & CAS \\
\hline & & & $\begin{array}{l}\text { Procurement of furnitures and office equipment for faculty of physical sciences } \\
\text { academic staff offices. }\end{array}$ & CHS \\
\hline
\end{tabular}

\section{Bot Special Intervention Utilization}

From the above table, one observes that the TETFund Interventions have indeed, impacted positively on Infrastructural Development in Ebonyi State University.

In addition to the foregoings, the TETFund Interventions have also reduced the financial pressures on the University.In other words, with the interventions, it has become possible for EBSU to reserve some funds from its IGR and use such reserved funds for infrastructural development.This is shown in table 3 below.

Table 3. Infrastructural development from EBSU IGR (2008-2012/13)

\begin{tabular}{llc}
\hline S/no & Name & Value of project \\
\hline 1 & Roadway Project (CAS) & $27,950.000$ \\
2. & Interlocking of Administrative quadrangle & $3,500.000$ \\
3. & TVE project (IshiekeAnnex) & $13,500,000$ \\
4. & Renovation of Prof.Ezike's & $1,182,800$ \\
& Building(Senior Staff(Quarters) & \\
5. & Bathroom toilets (CHS) & $6,302,044$ \\
6. & FHST Block project (CHS) & $14,000,000$ \\
7. & Library Accommodation & $1,000,000$ \\
8. & Hostel Building at Nwezenyi & $19,769,020$ \\
9. & Laboratory Tables \& Chairs & 75,000 \\
10. & Supply \& fixing of Burglary & 800.00 \\
11. & Renovation of Staff Quarters & $11,563,596$ \\
& VIP Guest & \\
12. & Planting of trees & 400,000 \\
13. & Internal fencing & 1848.300 \\
14. & SUG & 6195,129 \\
15. & FCM project CHS) & 5690,690 \\
16. & Gate House & 266,550 \\
17. & EBSUTH Mortuary & 977,995 \\
18. & Physical Planning Office & $7,959,080$
\end{tabular}


$\begin{array}{llr}\text { 19. } & \text { CHS Fencing } & 3,155.310 \\ \text { 20. } & 5,387,410 \\ \text { 21. } & \text { 45ysical Science Building TETfund } & 8,060,860\end{array}$

TOTAL

$102,367,427.61$

Source: EBSU Reports 2008-2012

\subsubsection{TETFund and Staff Development in EBSU}

We have noted earlier that TETFund interventions are anchored on the following areas: Normal Intervention; Library Intervention; Research grant; academic staff training and development; publication of journal; manuscript development; and conference attendance.Our research objective (ii) seeks to determine the impact of the TETFund Intervention on Staff development in Ebonyi State University.

In table 4 below, one observes that TETFund has sponsored about 46 academic staff to various degree programmes overseas between 2009 - 2012)

Table 4. Academic staff training and development

\begin{tabular}{|c|c|c|c|c|c|}
\hline $\mathbf{S} / \mathbf{N}$ & $\begin{array}{l}\text { Name of Staff } \\
\text { (Beneficiary) }\end{array}$ & Course and Level & $\begin{array}{l}\text { University where course is } \\
\text { tenable }\end{array}$ & $\begin{array}{l}\text { Course } \\
\text { Commencement }\end{array}$ & Total Allocation \\
\hline 1 & Albert.E. Okorocha & $\begin{array}{l}\text { Phd Molecular Physiology } \\
3 \text { Year }\end{array}$ & $\begin{array}{l}\text { Originally University of Liver } \\
\text { Pool, Later University of Leicester } \\
\text { UK }\end{array}$ & 2009 & $18,037,500$ \\
\hline 2 & Ikenna.E. U Egwu & $\begin{array}{l}\text { M.Sc Software } \\
\text { Engineering 1 Year }\end{array}$ & University of Sunderland & 2009 & $4,562,500$ \\
\hline 3 & Celestine Afiukwa & $\begin{array}{l}\text { Ph.D Data Analysis } 6 \\
\text { Months }\end{array}$ & University of Pretoria S/Africa & 2009 & $1,168,000$ \\
\hline 4 & Friday.N. Nweke & $\begin{array}{l}\text { Ph.D Data Analysis } 6 \\
\text { Months }\end{array}$ & University of Pretoria S/Africa & 2009 & $1,128,000$ \\
\hline 5 & Igwe.J. Offor & $\begin{array}{l}\text { M.Sc } \quad \text { Computer } \\
\text { Information Technology } 1 \\
\text { Year }\end{array}$ & $\begin{array}{l}\text { Sacred Heart University USA } \\
2009-2010\end{array}$ & 2009 & $6,750,000$ \\
\hline 6 & $\begin{array}{l}\text { Chibueze.O. } \\
\text { Anyigor }\end{array}$ & $\begin{array}{l}\text { M.Sc Computer Network } \\
\text { Tech. } 1 \text { Year }\end{array}$ & $\begin{array}{l}\text { NorthumbriaUniversity } \\
2009-2010\end{array}$ & 2009 & $4,462,500$ \\
\hline 7 & Igiri.N. Elom & $\begin{array}{l}\text { Ph.D Applied Sciences } 3 \\
\text { Years }\end{array}$ & $\begin{array}{l}\text { NorthumbriaUniversity } \\
2009-2010\end{array}$ & 2009 & $13,888,506$ \\
\hline 8 & $\begin{array}{l}\text { Chukwu Moses } \\
\text { Alieze }\end{array}$ & $\begin{array}{l}\text { M.Sc Chemical } \\
\text { Engineering } 1 \text { Year }\end{array}$ & University of Newcastle UK & 2010 & $5,580,000$ \\
\hline 9 & Charles Ukpai & $\begin{array}{l}\text { Ph.D } \quad \text { Electronic } \\
\text { Engineering } 3 \text { Years }\end{array}$ & University of Newcastle UK & 2010 & $15,844,000$ \\
\hline 10 & $\begin{array}{l}\text { Patrick Akata } \\
\text { Nwofe }\end{array}$ & $\begin{array}{l}\text { Ph.D } \quad \text { Electronic } \\
\text { Engineering } 3 \text { Years }\end{array}$ & University of Northumbria UK & 2010 & $15,884,000$ \\
\hline 11 & Joseph. C. Nwali & $\begin{array}{l}\text { M.Sc Chemical } \\
\text { Engineering } 1 \text { Year }\end{array}$ & University of Newcastle & 2010 & $5,332,000$ \\
\hline 12 & Ikpo Isaac Monday & M.Sc Accounting 1 Year & University of Hertfordshire & 2010 & $3,242,840$ \\
\hline 13 & Henry.F. Nweke & $\begin{array}{l}\text { M.Sc Computer Science } 1 \\
\text { Year }\end{array}$ & University of Bedfordshire UK & 2010 & $4,260,000$ \\
\hline 14 & $\begin{array}{l}\text { Michael } \\
\text { Chukwuma }\end{array}$ & M.Sc Chemistry 1 Year & Teeside University UK & 2010 & $3,936,000$ \\
\hline 15 & Uguru Edwin. H & M.Sc Physics 1 Year & University of Birmingham & 2011 & $6,798,300$ \\
\hline 16 & E. S Nwofe & M.A Film Studies 1 Year & University of Bradford & 2011 & $5,979,750$ \\
\hline
\end{tabular}




Henrietta Aja.N
Francis Nwebonyi
Ngozi. U Oledinma
Chukwuma
Anyigor
C. I Iduma

C.Elias Eze

Nwankwo Stephen Ndubisi

Nwankwo A.C

Nwigboji Simon Onwe

S. Ogbonnaya Uzor

Egwu.I. U Egwu

Amos Nworie

Grace. U Okoro

Ukpai. A. Eze

\section{Chidiebere Ekuma}

Jude. N. Ominyi

David.A Agom

Aaron.B. Nwedu

Joy Oko Uka

Onwuchekwa Ogah

Dr. Emeka .D Ogiji

Dr. Uchenna. S Ezenkwa

Ewenighi Chinwe. Ph.D Nnamdi Azikiwe $\mathrm{O}$

Azi Simon Onyema M.Sc Med Lab.

Nwakpu Onuoha. K Ph.Debsu Med.MCB

Oko Constance. C M.Sc.

Emma.O. Ezenkwa M.Sc. Waste Management

Boniface.N. Ukwa

Ph.D UNN Medical MCB

Iteshi .A. Chinedu

M.Sc Computer Sc.

Fidelis Azi

M.Sc. Food MCB
University of Manchester

2011

2011

2011

2011

2011

University of Manchester UK

University of Bedfordshire UK

2011

2012

Newcastle University UK

Queen Margaret University UK

2012

Queen Margaret University UK

University of West of England UK

2012

2012

2012

University of IOWA USA

2012

2012

2012

University of Salford Uk

2012

University of Northampton UK

2012

University of Northampton UK

2012

University of Northampton UK

2012

2012

2013

Washington State University

2013

2013

University of Ibadan Nigeria

University College London-Split 2013 Site Ph.D Uk

University of The West of England

2013 Bristol UK

University of Winni Peg 2013 Canada-Split Sit Ph.D

University of Aberdeen Scotland.

2013 UK

Cranfield University UK

2013

Centre for Disease Control-CDC Atlanta,Geogia USA Split Site Ph.D

University of Bedfordshir UK

Nnamdi Azikiwe University
$5,788,500$

$6,798,300$

$5,686,500$

$6,349,500$

$6,859,500$

$5,265,750$

$5,781,750$

7,916,812

7,916,812

$6,018,000$

$13,059,060$

$2,273,520$

$6,018,000$

$6,018,000$

$6,808,350$

$4,819,500$

$4,819,500$

$4,819,500$

5,500,350

$6,976,000$

5,928,000

350,000

$3,770,000$

$5,590,000$

$1,996,000$

5,772,000

$6,240,000$

4,800,000

$281,589,100$
350,000 
The table also shows the degree in view, universities where courses are tenable and the total amount in naira on each candidate.So far, N281,589,100 has been spent in this direction.It is hoped that by the time the candidates complete their courses and return to the University, there will be a big boost to the quality of academic staff in the University.

In addition to the foregoing, the TETFund has also sponsored 439 academic and non-academic staff of the University to national and international conferences and seminars.Records show that the areas of interest for such sponsorship is human resource/capacity development.According to the TETFund Desk Officer in EBSU, the ratios at which academic and non-academic staff benefit from such conferences are 70:30 respectively.N75,000,000 has so far been spent in this direction between 2011-2013 years as shown in table 5 below.It is abundantly clear from the foregoing that the TETFund has indeed impacted positively on Staff development in Ebonyi State University as shown on table 5 below.

Table 5. Staff conference attendance (2011-2013)

\begin{tabular}{lllll}
\hline S/N & $\begin{array}{l}\text { Date } \\
\text { Release }\end{array}$ & $\begin{array}{l}\text { No } \\
\text { Staff }\end{array}$ & $\begin{array}{l}\text { of } \\
\text { Released }\end{array}$ & Remarks \\
\hline $\mathbf{1}$ & $21 / 03 / 2011$ & 70 & $7,780,247$ & $\begin{array}{l}\text { The ratio of } 70: 30 \text { to Academic and non-academic apply on } \\
\text { the disbursement of these funds. }\end{array}$ \\
$\mathbf{2}$ & $17 / 02 / 2012$ & 4 & $2,256,000$ & \\
$\mathbf{3}$ & $21 / 2 / 2012$ & 47 & $7,860,935$ & \\
$\mathbf{4}$ & $16 / 03 / 2012$ & 25 & $2,483,079$ & \\
$\mathbf{5}$ & $28 / 05 / 2012$ & 16 & $2,686,026$ & \\
$\mathbf{6}$ & $09 / 07 / 2012$ & 59 & $12,249,850$ & \\
$\mathbf{7}$ & $21 / 11 / 2012$ & 97 & $10,759,990$ & \\
$\mathbf{8}$ & $04 / 12 / 2012$ & 65 & $12,093,652$ & \\
$\mathbf{9}$ & $15 / 02 / 2013$ & 25 & $8,702,839$ & \\
$\mathbf{1 0}$ & $07 / 04 / 2013$ & 26 & $4,266,422$ & \\
$\mathbf{1 1}$ & $05 / 05 / 2013$ & 5 & $3,540,960$ & \\
& & $\mathbf{4 3 9}$ & $\underline{\mathbf{7 5 , 0 0 0 , 0 0 0}}$ & \\
\hline
\end{tabular}

Source: TETFund 2013

\subsubsection{TETFund and Research/Academic Growth in EBSU}

Ebonyi State University is committed to the recruitment of highly qualified academic staff to accelerate its academic growth as well as meet the National Universities Commission (NUC) Staff/Student ratio.In this regard, the number of recruited academic staff improved tremendously from 590 in 2004/2005 academic year, 667 in the $2006 / 2007$ session to 816 in 2007/2008. However, in the 2008/2009 academic session, the number dropped to 728 (Academic Planning Office, EBSU, 2010).The drop, according to the Institution's Academic Planning Director, was designed to address the then lopsided ratio between lecturers 1 and below and other categories due to the desire to achieve the 20:35:45 ratio of professorial cadre to other cadres in accordance with the NUC guideline.Hence, by the end of the 2010 academic session, EBSU has achieved 19.3 per cent in the professorial cadre; 26.9 per cent in the senior lecturer cadre from 23.4 per cent in the previous year; and 53.8 per cent from 56.4 per cent in the lecturer 1 and below cadres. (EBSU, Academic Planning Statistics, 2013).

On the area of Research, the TETfund had allocated N37,000,000 as research grant for the 2009-2012 periods. Out of this sum, N,292,020 has so far been disbursed on merit to academic staff of the University who had successfully applied for research grant.Table 6 , shows the comprehensive list of recipients, areas of research and at what stage research activities are: 
Table 6. Research grant

\begin{tabular}{|c|c|c|c|}
\hline $\mathbf{S} / \mathbf{N}$ & Research title & $\begin{array}{l}\text { Lead Researcher } \\
\text { (i.e. Team leader) }\end{array}$ & $\begin{array}{l}\text { Statues } \\
\text { Research }\end{array}$ \\
\hline 1 & $\begin{array}{l}\text { Assessment of control urinary schistosomiasis among school } \\
\text { age children in the most Endemic Local Govt Areas of } \\
\text { Ebonyi State }\end{array}$ & $\begin{array}{l}\text { Dr. Chigozie Jessy } \\
\text { Uneke and } 5 \text { others }\end{array}$ & $\begin{array}{l}\text { Ongoing } \\
\text { progressing } \\
\text { successfully. }\end{array}$ \\
\hline 2 & $\begin{array}{l}\text { Phytochemical characterization and comperative studies of } \\
\text { mosquito repellent activity of essential oils from some plant } \\
\text { extracts. }\end{array}$ & $\begin{array}{l}\text { Uraku,A. J and } 6 \\
\text { others }\end{array}$ & -do- \\
\hline 3 & $\begin{array}{l}\text { Corelation of some heavy mental contents of foods and water } \\
\text { in ebonyi state with their levels in blood of resident and } \\
\text { associated biochemical changes. }\end{array}$ & $\begin{array}{l}\text { Dr. Emmanuel } \\
\text { Ike.U. and } 6 \text { others }\end{array}$ & -do- \\
\hline 4 & $\begin{array}{l}\text { Evaluatuon of the effect aqueous and ethanol extracts of } \\
\text { leaves and seeds of moringa oleifera in albino }\end{array}$ & $\begin{array}{l}\text { Mr. Aja Patrick .M. } \\
\text { and } 6 \text { others }\end{array}$ & -do- \\
\hline 5 & $\begin{array}{l}\text { Characterization and comparison of CTX-M-Extended } \\
\text { spectrum Beta lactamase producing eschericha coli from } \\
\text { human clinical and wild birds (Pigeon, Bat Hawk, } \\
\text { Kite)samples from ebonyi state of Nigeria. }\end{array}$ & $\begin{array}{l}\text { Dr. Ifeanyichukwu } \\
\text { Iroha and } 9 \text { others }\end{array}$ & -do- \\
\hline 6 & $\begin{array}{l}\text { Enhancing plantain and banana (musa spp)propagation } \\
\text { through Biotechnology and Delivery of improved variaties to } \\
\text { subsistence farmers in South-East Nigerian }\end{array}$ & $\begin{array}{l}\text { Dr. H.O.Selebe and } \\
6 \text { others }\end{array}$ & -do- \\
\hline 7 & $\begin{array}{l}\text { Genetic diversity of cultivated Nigerian sesame and its } \\
\text { relationship with Agro morphological fatty Acid. }\end{array}$ & $\begin{array}{l}\text { Dr. Nweke F. N and } \\
5 \text { others }\end{array}$ & -do- \\
\hline 8 & $\begin{array}{l}\text { Acute Toxicity and effects of low Herbicides and two local } \\
\text { Herbs on some Biochemical parameters in fresh water fishes. }\end{array}$ & $\begin{array}{l}\text { Dr. U.A Ibiam and } 6 \\
\text { others }\end{array}$ & -do- \\
\hline 9 & $\begin{array}{l}\text { Mass production of housefly maggot meal and effect on its } \\
\text { diets on eggs development }\end{array}$ & $\begin{array}{l}\text { Prof. Dr. Jonny } \\
\text { Ogunji and } 6 \text { others }\end{array}$ & -do- \\
\hline 10 & $\begin{array}{l}\text { Sub-sector linkage and contributions of Agric Interventions to } \\
\text { Ebonyi State Economy. }\end{array}$ & Prof. Aja Okorie & -do- \\
\hline 11 & $\begin{array}{l}\text { Genetic Diversity if cultivated Nigerian sesame using AFLP } \\
\text { maker. }\end{array}$ & $\begin{array}{l}\text { Dr. F.N Nwalo and } \\
5 \text { others }\end{array}$ & -do- \\
\hline 12 & $\begin{array}{l}\text { sub-sector Linkages and contributions of agricultural } \\
\text { interventions to ebonyi state economy }\end{array}$ & $\begin{array}{l}\text { Prof. Aja Okorie } \\
\text { and } 7 \text { others }\end{array}$ & -do- \\
\hline 13 & Acute Toxicity of agricultural Hebicites & $\begin{array}{l}\text { Dr. U. A Ibiam and } \\
6 \text { others }\end{array}$ & -do- \\
\hline 14 & Mass production of housefly as fish Diets & $\begin{array}{l}\text { Prof. Dr. J.O. } \\
\text { Ogunji and } 6 \text { others }\end{array}$ & -do- \\
\hline
\end{tabular}

Source: TETFund Desk Office, EBSU

\subsection{Evaluation/Implications for Sustainable Development}

We have noted earlier in this study that EBSU as a fledging University in the 1990s before its elevation to autonomous status in 2000, had its campus located in three premises which were inherited from older institutions in the state.Administrative buildings and classroom blocks which existed during that time, were renovated from the IGR of the University basically from Students School fees. We also noted that there was scarcely any fund at 
the University's disposal after routine administrative costs to be used for any meaningful infrastructural development.Thus, infrastructural development was at very poor stage, library, teaching/research facilities were glaringly lacking or in very short supply.However, from the year 2000, when EBSU started receiving allocations from the TETFund, situations started improving gradually.For instance, from the TETFund interventions, EBSU has been able to experience a boost in infrastructural development; many academic staff have also received research grants; many have been sponsored to local and international seminars and conferences in addition to TETFund sponsored oversea training and retraining of academic staff as noted earlier.Indeed, TETFund Interventions have had some positive impact on the growth of the Ebonyi State University and the implications of these for sustainable development is quite obvious.

If sustainable development as stated in our literature is indeed, a "development that meets the needs of the present without even compromising the ability of future generations to meet their own needs" then the barometer/indices for measuring this as it concerns Ebonyi State University must include: availability of infrastructure; infrastructural growth rate; academic growth and development; research and innovations, staff development; amongst others.Our study has shown that the above areas have witnessed a big boost sinceTETFund interventions in EBSU.

Furthermore, the definition of sustainable development as expanded by the World Commission on Environment and Development (WCED) (1987) and cited in Nduanya (2001), builds development efforts on man whom it was believed should be the purveyor and end of development efforts. The efforts of EBSU management on staff development through overseas scholarships, training/retraining via seminars and conferences et.c; are supportive of sustainable development as expanded by WCED.Sustainable development in a University, involves a tripartite approach; viz: Infrastructure, Staff (academic \& non-academic) and students.There must be a holistic efforts in these areas for development to be described as sustainable.

\section{Conclusion}

The TETFund Interventions are anchored on: Normal Intervention; library; research grant; academic staff training and development; publication of journal; manuscript development; and conference attendance.From the study, TETFund, has done handsomely well in these areas, it behooves on management of Ebonyi State University to intensify efforts on meeting all necessary requirements for access and release of all approved funds from TETFund.It is the position of this paper, that knowing the place of education in the development of any nation, the governments of Nigeria must not relent in ensuring a steady and adequate funding of tertiary education in the country.Though, no government can adequately fund tertiary education in the true sense of the word, education fundings should occupy a pride of place in the budgets of the country with a view to making it affordable to all citizens of the Nigeria.

\section{Recommendations}

Despite the TETFund interventions, tertiary institutions in Nigeria still lack funds necessary to upgrade the institutions to international standard.This situation is due to the fact that tertiary education is cost-effective and, even the funds approved by TETFund, are not always fully accessed by the beneficiary institutions.Based on these facts, the following recommendations are advanced.

- To make it easier for institutions to fully access approved TETFund, there is need to reduce or eliminate entirely the level of bureaucratic bottlenecks often associated with accessing approved funds.Such delays are often in the areas of examining request/applications for funds, scrutinizing the attendant feasibility studies and monitoring/certifying of executed projects before further releases are made; which often, are not devoid of sharp practices.

- Since after an initial release, further funds are disbursed on satisfactory execution of projects, it is important that projects are assigned to only contractors who are certified to be honest and competent.Delays in project execution are often caused by fraudulent/incompetent contractors who, after unnecessary delays in executing contracted projects, only come back seeking for variations of contract terms on the easy excuses of market price fluctuations.As fresh requests for variations of contract terms involve bureaucratic processes, delay in completion of projects become inevitable which frustrates beneficiary institutions making it impossible to complete projects on schedule so as to enable them access further funds as and when due.

- Having noted that University education is cost-effective, donor agencies and philanthropic individuals and groups, should assist governments in funding tertiary education in the country.

- To improve the volume of Internally Generated Revenue (IGR) in Nigerian tertiary education institutions, Ebonyi State University in particular, should embark on business ventures.Such business ventures may include, 
investment on shares; production of customized bottled water; ensuring that no other brand of bottled water is sold within all the campuses of the institution; making the University press very functional and business-oriented; embarking on vehicle energy supply within the campuses; improving the capacity of its Microfinance Bank; embarking on Hostel accommodation, building of functional staff guest house amongst others.In these ways, the IGR of the University would improve and dependence on the state government will be reduced.This will also divert attentions from the easy options of increasing school fees with its attendant implications on indigent students of Ebonyi State.

- Good governance and transparency on the part of the TETFund and beneficiary institution's management, should form the hallmark of the Funds Operations to ensure accessibility and result-oriented utilization of accessed funds.

\section{Acknowledgements}

We immensely thank EBSU Management, the TETFund Desk Officer, EBSU, Mr. Anthony Isu for supplying the data for this manuscript and Mrs. NjokuCelestina for her patience in typing it.

\section{References}

Abah, E. O. (2003). Nigeria's Human Development Programme and Poverty Eradication in Ebonyi State: A Paper Presented at a Conference on Celebration of World Poverty Eradication Day at Abakaliki.

Academic Planning Handbook, EBSU, 2010.

Ajayi, I. A., \& Ekundayo, H. T. (2006). Funding Initiatives in University Education in Nigeria - Being a Paper Presented at the National Conference of Nigeria Association for Educational Administration and Planning (NAEAP) Enugu State University of Science and Technology, Enugu State. pp. 76-78.

Eboh, E. C. (1995). Sustainable Development: The Fhoery and Implication for Rural Nigeria. In Eboh et al. (Eds.), Rural Development in Nigeria: Concepts, Processes and Projects. Enugu, Auto-century Publishing Company.

Ebonyi State University Law. (1999).

Ebonyi State University Reports. (2008-2012).

ETF. (2011). About TETFund. Retrieved February 1, 2014, from http://www.tetfund.goo.ng

Narain, L. (1986). Principles and Practice of "Public Enterprises Manager". S. Chand and company, New Delhi, India.

Nduanya, M. O. (2001, July). Development.Journal of Arts and Social Science Review, 1(1).

Nkwede, J. O. (2009). Nigerian Universities and the Challenges of Financial Administration: A Random Analysis.A Journal of the Nigerian Public Administration Review, 1(i).

Oscar, E. I. C. (2012). Capacity Development in the Nigerian Public Sense: A Study of Edo State, Nigeria. Ph.D Thesis, Ebonyi State University, Abakaliki, Nigeria.

Samuelson, P. A. (1954). The Pure Theory of Public Expenditure. Review of Economics and Statistics, 36(4), 387-389. http://dx.doi.org/10.2307/1925895

TETFund Desk Office, Ebonyi State University, Abakaliki.

The World Bank. (1987, June). Nigeria and the World Bank. Washington D.C. Information Affairs Dept.

Udu, L. E. (2014). Human Capacity Building In Selected Local Government Areas of Ebonyi State - The Role of Non-Governmental Organizations (NGOs) and Development Agencies (2000-2008). Journal of Business and Management, 3(1), 25-41. Retrieved from http://www.todayscience.org

UNDP. (2001). Management of Sustainable Human Development at Local Government Level Modules 1-4, UNDP Training Manual.

United Nations Development Report: Human Development Report, 1994. UNDP.

www.ebsu-edu.net; Friday, $7^{\text {th }}$ February 2014.

\section{Acronyms}

EBSU - Ebonyi State University

CAS -College of Agricultural Sciences

CHS -College of Health Sciences

ASUTECH - Anambra State University of Technology

ESUT -Enugu State University of Science \& Technology

EBSUC -Ebonyi State University College 


\section{Copyrights}

Copyright for this articleis retained by the author(s), with first publication rights granted to the journal.

This is an open-access article distributed under the terms and conditions of the CreativeCommons Attribution license (http://creativecommons.org/licenses/by/3.0/). 